\title{
Factors inhibiting the adoption of ICT by Tamale Polytechnic lecturers for the training of the middle-level- manpower professionals in Ghana.
}

\author{
Zakaria Abukari \\ Lecturer, Dept. of Computer Science \\ Tamale Polytechnic \\ Tamale, Ghana
}

\begin{abstract}
Although the Ghanaian polytechnics have had computers and varied levels of ICT development for almost two decades now, ways to create effective IT-enabled teaching and learning methodologies have evolved slowly and patchily. This situation is gradually making the polytechnic trainees incompatible in the digital-enabled job markets. Coupled with this development is the fact that the internet has become the single and largest library and knowledge reservoir thus making it indispensable in the teaching and learning ambit. It has therefore become imperative and collective responsibility to identify the factors that inhibit the adoption of the technology by the tertiary teachers especially the Polytechnic Teachers Association of Ghana (POTAG) fraternity to bridge the digital gab to add more value to the polytechnic teachers and graduates and to raise their relevance in the industry. This research therefore comes in, with the case of the Tamale Polytechnic, to explore the challenges and recommend strategies to stakeholders. Descriptive survey methodology, which is capable of collecting background information and hard to find data without the researcher motivating or influencing respondents' responses, was used to arrive at our findings.
\end{abstract}

Keywords: ICT; Teaching and learning; Policy; LCD Projector; Sample size, Sample population

\begin{abstract}
1. INTRODUCTION
Information and Communication Technology is emerging now as the pivot of change in every facet of life today and for this reason, it is widely embraced in the society today. Matthew(1997) states that the use of information and communication technology is clearly shaping the ways in which we learn, work and spend our leisure. As such, our success as individuals or as a nation depends on our ability to understand and use ICT. Today no one can afford to ignore the importance of computer technology in one's everyday life.
\end{abstract}

Teachers are expected to work paying more attention to students' autonomy and independence in the teaching and learning process. ICT is the major enabler in this direction. Much the same, the role of the teacher as a facilitator of the process should not be underestimated. In this era of digitization, it is time to question the old values of the traditional forms of education but on the other hand student-teacher collaboration can be mutually beneficial. Technology has created favourable conditions for teachers to help students to be engaged equitably as active partners in learning. Pedagogical communication is evidently important to renew the teacher-student communication style as new digital forms require new approaches not only on the process of teaching but also to the way of interacting. Pedagogical communication is known to be the interaction between a teacher and a student to achieve certain educational goals.

The quality of education depends, to a large extent, on the quality of teachers involved in its development and delivery. A qualified teacher will acknowledge the needs and interest of students, allowing them to learn at their own convenience, encourage learning, where necessary, intervene through remedial and enrichment instructions among others (MIE, 2004). ICT is considered a powerful tool for educational change and reform. Appropriate use of ICT can improve quality of education and connect learners to real-life situations (Lowther, et. al., 2008);(Weert and Tatnall, 2005). As Weert and Tatnall (2005) have stated, learning is a lifelong ongoing activity where learners change their expectations by seeking knowledge through ICT tools such as the internet and other electronic simulations that depart from the traditional approaches. Skills in using ICT will be an indispensable prerequisite for these learners.

Despite these outlined benefits of ICT in the teaching and learning environment, teachers in the tertiary institutions in Ghana are not yet harnessing these opportunities. It is against this backdrop that this research is attempting to investigate the underlying factors that demotivate the use of ICT in teaching and learning in the Tamale Polytechnic, an environment that does not differ much from the other nine (9) polytechnics in the country. Based on our findings, the appropriate recommendations shall be made to improve the situation. The fact remains intangible that the way forward for students' autonomy, effective teaching and learning is ICT.

\section{STATEMENT OF THE PROBLEM}

There have been exponential increases in the acquisition of computers in schools not just in the Western countries, but increasingly in developing ones as well. Although it is almost two decades, ways to use them effectively in many schools in the underdeveloped countries including Ghana have evolved slowly and patchily. The technological revolution has been beset by many factors that have kept the implementation of the educational 
technology below the expectations in our societies. Whilst the Western countries, through IT-enabled teaching and learning systems, are gradually shifting from the traditional classrooms to the eClassrooms, developing countries are yet to take the advantage. In Ghana, there are adequate ICT facilities in the tertiary institutions such as computers, laboratories, high speed internet connections etc. yet many of the lecturers still deliver their lessons the traditional way through the use of blackboards (now whiteboards), lecture notes popularly called "handouts", manual assignments etc. One will question why teachers do not take advantage use of ICTs at their disposal to join the stream of change in teaching and learning. According to Gregoire et. al (1996), John and Sutherland (2004), the practical skills of the teacher and his/her attitude towards the use of ICT in teaching and learning contribute greatly to the students development. This research is therefore coming in to uncover the challenges, bottlenecks or call them inhibiting factors to the teachers' adoption of ICT in the tertiary institutions in Ghana using the Tamale Polytechnic as the case.

\section{OBJECTIVES OF THE STUDY}

This study seeks to explore the factors inhibiting polytechnic teachers' use of ICT in teaching and learning. To achieve our goal, the research addresses the following specific objectives:

- To find out the barriers hindering the integration of ICT into teaching and learning in Tamale Polytechnic.

- To assess the ICT infrastructural capacity for teaching and learning, in Tamale Polytechnic

- To determine the level of teacher's ICT knowledge and skills for teaching and learning in Tamale Polytechnic

- To examine the attitudes of teachers in the use of computers in Tamale Polytechnic.

- To recommend strategies for stakeholders to adopt for institutionalizing ICT use in teaching and learning.

\section{SIGNIFICANCE OF THE STUDY}

The impact of ICT on education is enormous. In the digitalenabled job markets, a graduate without IT competence is halfbaked. The internet has become the single and largest library and knowledge reservoir making it therefore indispensable in the teaching and learning ambit. In this regard, identifying and addressing the factors that inhibit the adoption of the technology by the tertiary teachers especially the polytechnic teachers who are mandated to train the middle-level-manpower, will bridge the teaching digital gab adding more value to the polytechnic teachers and graduates making them more industry relevant. In specific terminologies, the importance of this research is summarized as:

i. The work will provide guidance to improve the use of ICTs in teaching and learning

ii. Teachers and graduates will be more industry compatible and relevant if the recommendations to the findings are implemented.

iii. This will also serve as a springboard for other researchers

iv. The research will showcase the impact of ICT in teaching and learning.

\section{METHODOLOGY}

Two principal research techniques were used. Formal and informal participatory methods were used to obtain the needed data for analyses. The informal methods involved observation and interviews of key stakeholders whilst the formal methods included the use of questionnaire for descriptive survey. According to Busha and Harter (1980) descriptive survey is capable of collecting background information and hard to find data and the researchers would not have the opportunity to motivate or influence respondents' responses. The technique is specially recommended for research where attitudes, ideas, comments and public views on a problem or issue are studied Sproull (1995), Iddrisu (2009).

A total of eighty (80) lecturers were randomly selected from ten (10) departments of the sixteen tertiary departments. The sample size was calculated according to Yamane (1973). The formula is provided below.

$\mathrm{n}=\frac{N}{1+N(e)^{2}}$

where

$\mathrm{n}=$ is the required sample size. $\mathrm{N}=$ the population size $\mathrm{e}=$ Tolerable error (which in this study was pegged at 0.05 ). Proportional allocation was used to obtain the size that is supposed to be taken from each stratum (Table 1)

Table 1: Sample size

\begin{tabular}{|c|c|c|c|c|}
\hline No & Name of Department & Population & Calculation & $\begin{array}{l}\text { Sample } \\
\text { size }\end{array}$ \\
\hline 1 & Computer science & 8 & $8 / 100 \times 80$ & 6 \\
\hline 2 & Accountancy & 16 & $\begin{array}{l}16 / 100 \\
\times 80\end{array}$ & 13 \\
\hline 3 & Sec. and mgt studies & 11 & $\begin{array}{l}11 / 100 \\
\times 80\end{array}$ & 9 \\
\hline 4 & HCIM department & 8 & $8 / 100 \times 80$ & 6 \\
\hline 5 & Marketing & 10 & $\begin{array}{l}10 / 100 \\
\times 80\end{array}$ & 8 \\
\hline 6 & $\begin{array}{l}\text { Mechanical } \\
\text { engineering }\end{array}$ & 9 & $9 / 100 \times 80$ & 7 \\
\hline 7 & Building Technology & 10 & $\begin{array}{l}10 / 100 \\
\times 80\end{array}$ & 8 \\
\hline 8 & $\begin{array}{l}\text { Agricultural } \\
\text { engineering }\end{array}$ & 11 & $\begin{array}{l}11 / 100 \\
\times 80\end{array}$ & 9 \\
\hline 9 & Industrial Arts & 6 & $6 / 100 \times 80$ & 5 \\
\hline 10 & Statistics department & 11 & $\begin{array}{l}11 / 100 \\
\times 80\end{array}$ & 9 \\
\hline & Total & 100 & & 80 \\
\hline
\end{tabular}

Both closed-ended and opened-ended questions were used in the questionnaire. The opened-ended questions were used to allow the respondents to express themselves without any given limit. The questionnaire was adapted and modified from Rodden (2008). The data collected was checked for consistency. Statistical Package for the Social Sciences (SPSS) was used for the analysis. 


\section{PREVIOUS WORKS REVIEW}

Reviewing previous works on related topic of research according to (Cisse, 2006) is a prudent approach to reducing repeated errors. Many researchers have looked at ICTs and education. Computers became common in the 1980's when personal computers became accessible to consumers. Since then there has been government policies that encouraged the mass production of computers for schools. Several researchers suggested that ICT is now an essential part of the education process (Pelgrum and Law, 2003); Hepp et. al (2004); Kozma (2008). Educational systems need to prepare students to adjust to and persist in this new technologically compelled society. This means preparing students for "ultimate learning in an information society" (Pelgrum and Law, 2003). In addition to this, early promoters of ICT integration into education saw it as a facilitator for change, nurturing skills in problem solving and critical thinking, as well as the development of student centred learning (McGrail, 2005).

According to Kozma (2008) there are three grounds for the introduction of ICT into education. The first one is the economic ground which refers to the role it can play in preparing students as future workers and in supporting financial development. The second is the social ground where ICT investment aims to elevate knowledge sharing, encourage cultural creativity, increase civic participation, make government services more accessible and finally enhance social cohesion. The third and final ground is the educational and pedagogic rationale where ICT can advance educational reform and advance educational management structures. Similarly, Hepp et. al (2004) broadly concur, finding three reasons for the use of ICT in education: the development of new skills for the information age, increased efficiency and the development of quality learning.

Whereas Kozma (2008) posits that there are three rationales for the introduction of ICT into education, Hawkridge (1990) proposes four rationales for the utilization of computers in schools. He notes these as social, vocational, pedagogical and catalytical. The social and vocational grounds point to the increased use of ICT in all spheres of human activity. The pedagogical and catalytically rationales relate to the effects of technology on students and schools. There are various views of others Bigum(1997); Hawkridge(1990); Drent and Meelissen (2008).

The use of ICTs improves all forms of information exchange, observation, learning and teaching. There is a great amount of research describing how ICT is being used effectively and efficiently in schools. DFES (2003) set out the aims for effective use of ICT in teaching and learning as broadening prospects with more opportunities for creative expression, flexibility to study when, where and how best suits the need and preferences of individual, increased motivation through learning that stimulates interest, wider accessibility to participation and learning, reasonable choices about when, when not and how to use new technology to enhance, improve and sustain learning and teaching. It further suggests that ICT can make essential contribution to teaching and learning across all subjects and ages. Thus it can engage, and inspire children and young people and meet their individual needs and preference. Cox (1999) also suggested some benefits of using ICT in lessons:

- Increased commitment to learning tasks/jobs

- Improved enjoyment and interest in learning the subject

- Increased in self -directed independent learning

- Enhanced self-esteem leading to expectations of achieving goals.

Becker (2001) documented a study of over 4000 teachers in the USA and suggested the following objectives of using ICT in lessons

- Getting ideas and information

- Expressing self in writing

- Understanding subject skills just taught

- Learning computer skills and

- Analyzing information

Students can derive from the effective and efficient use of ICTs in the teaching and learning process such as increased motivation to stay on-task, behave well and produce higher quality output, learn more individual and at their own pace, do things they cannot do using traditional methods and resources and finally, a combination of several subjects into project-based activities.

\subsection{Identified barriers to ICT adoption in education at other places}

Information Technology integration into teaching and learning is the application of technology to help, enhance, and speed-up student knowledge (Omwenga et. al, 2004). This means more than simply teaching learners how to use computers. The technology is rather a means for improvement in education and not an end in itself. Muriithi (2005) has argued that in Kenya, like most developing countries ICT is still at the awareness level limiting its application to basic computer literacy and office clerical tasks. A study carried out by Organization for Economic Cooperation Development (OECD) in 2009 and cited in Rodden (2010) confirmed that there are a number of factors that inhibit the use of ICT in education. These barriers included inconsistent number of computers to students, a deficit in maintenance and technical assistance and finally, a lack of computer skills and/or knowledge among teachers (OECD, 2009). Jenson et. al (2002) classified these barriers as limited equipment, inadequate skills, minimal support, time constraints and lack of interest or knowledge by teachers. In a related research report carried out by British Educational Communications and Technology Agency (BECTA) in 2004, some important barriers were identified. These were lack of confidence, accessibility, lack of time, fear of change, poor appreciation of the benefits of ICT and age. Ertmer (1999) concurs with Schoepp (2005), asserting that if teachers are sensitized or informed of such barriers, they can introduce strategies to overcome them.

According to Iddrisu (2009) although important lessons may be learned from best practices around the world, there is no one formula for determining the finest level of ICT integration into the educational system. Significant challenges that policy makers, education administrators and other stakeholders need to consider include educational policy planning; infrastructure; language and content; capacity building; and financing. In fact it is a tall list of research on the challenges Ertmer (1999); Balanskat et. al (2006); Pelgrum (2001); BECTA (2004). As stated by Iddrisu (2009), there is no any single formula but strategies with local content will be the best approach to integrating ICT into teaching and learning. In this research, we have leveraged importance on teacher related barriers that bother much of this research's objectives.

\subsubsection{Teacher related barriers}

The teacher is the principal stakeholder in the teaching and learning process and crucial in determining ICT use in the classroom 
(Baylor and Ritchies, 2002). Gressard and Loyd (1985) put it to all that teachers' attitude towards ICT is a key factor which determines successful integration, while Jegede (2008) identifies the teacher as a key instigator in fostering ICT integration in teaching and learning. Teacher related barriers are summarized as:

i. Lack of knowledge or competence. A teacher's lack of knowledge serves as a considerable challenge to the use of computers in teaching methods and practices. Tezci (2009) as cited in Rodden (2010) posits that if teachers have a high level of ICT knowledge, then there will be a higher level of ICT use in education. These barriers according to some researchers vary from country to country. Pelgrum (2001) found that lack of knowledge/competence in technology, among teachers in developing nations, is the primary obstacle to the uptake of ICT in education.

ii. of confidence Several studies conducted reveal that the lack of confidence prevents teachers from using ICTs. A BECTA report in 2004 adumbrates that many teachers who are untrained in ICT are not prepared to use them in the classroom or in front of students who might probably know more than them. According to Jegede et. al (2008) as teachers become more grateful of the use of ICTs as a pedagogical aid, attitudes and interest mostly become positive. Causes of lack of confidence include fear (Beggs, 2000) whilst Balanskat et. al (2006) attribute it to limited ICT knowledge of the teacher.

iii. $\quad$ Fear for change

Computer fear is a key barrier, limiting or preventing the use of ICT by teachers according to a BECTA(2004) report.

iv. Lack of training Most researchers have identified this barrier frequently cited Pelgrum (2001); Rodden (2010); Bingimlas (2009); BECTA (2004); Trotter (1999); Gomes (2005). Osborne and Hennessy (2003) found that teacher training is essential if they are to integrate new tools and approaches in education.

v. Age

Kumar et. al (2008) maintain that age is an important factor to the use of ICT in teaching and learning process. Lee (1997) points out that many older teachers did not have any computer education when in school and as a result are in need of training to allow them to make use of computers in their work. Cavas et. al (2009) conclude that there is a connection between teacher's age and their computer attitudes. Another study by Korte and Husing (2007) concludes that younger teachers appear to be less worried about using ICTs in learning.

\subsection{Government policy on ICT adoption in Ghanaian schools.}

The government of Ghana is poised for transforming the agrobased economy of the country into knowledge-based economy (Dzidonu et.al, 2003). The need for ICT-based training in the tertiary institutions, especially the polytechnics that are mandated to produce practical skills-oriented graduates, has been dominating government talk shows. The government acknowledges that the integration of ICT into the Education system will result in the creation of new opportunities for learners and teachers to engage in new ways of knowledge acquisition hence the rationale behind its ICT policy statement which is an epitomized version of the ultimate goal to transform the educational system. The policy document provides a clear policy direction for what needs to be done and how it is intended to be done. Unfortunately, programmes of implementation of the outlined policy actions have so far been crawling.

\section{RESULTS AND DISCUSSIONS}

The demographic characteristics and background information of the respondents were first looked at in the obtained data. This was followed with the discussions of the findings in connection with the research objectives.

\subsection{Demographic characteristics and background information}

The results obtained indicated that $78.8 \%$ of the respondents were males whilst the remaining $21.2 \%$ were females (Table 2). It was quite interesting to note that majority of the respondents aged between 46 and 60 years. This further implies that the polytechnic should be replacing majority of its teachers in the next 14 years (figure 1).

\section{Table 2: Gender of respondents}

\begin{tabular}{|l|r|r|}
\hline Gender & Frequency & \multicolumn{1}{|c|}{ Percent } \\
\hline Male & 63 & 78.8 \\
\hline Female & 17 & 21.2 \\
\hline Total & $\mathbf{8 0}$ & $\mathbf{1 0 0 . 0}$ \\
\hline
\end{tabular}

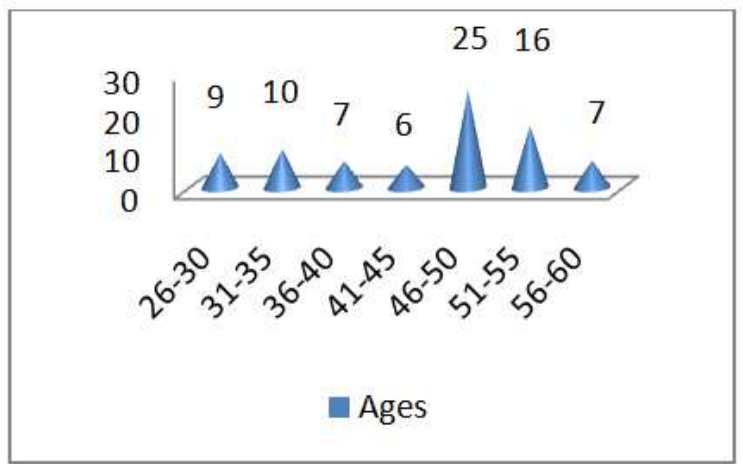

Figure 1 Ages of respondents

A scrutiny of the collected data summarized in table 3 revealed that the polytechnic has almost got the full compliments of lecturers. A total of 62 of the lecturers representing $77.5 \%$ are master degree holders. A few lecturers are undergrads whilst three (3) were terminal $\mathrm{PhD}$ holders. 
Table 3: Highest Level of Education Attained

\begin{tabular}{|l|r|r|}
\hline Certificate & Frequency & Percent \\
\hline HND & 5 & 6.3 \\
\hline 1st Degree & 10 & 12.5 \\
\hline Masters & 62 & 77.5 \\
\hline Doctorate & 3 & 3.8 \\
\hline Total & $\mathbf{8 0}$ & $\mathbf{1 0 0 . 0}$ \\
\hline
\end{tabular}

The study discovered that more than $50 \%$ of the polytechnic lecturers have a minimum of six (6) years experience in the polytechnic. The old adage that "experience is the best teacher"

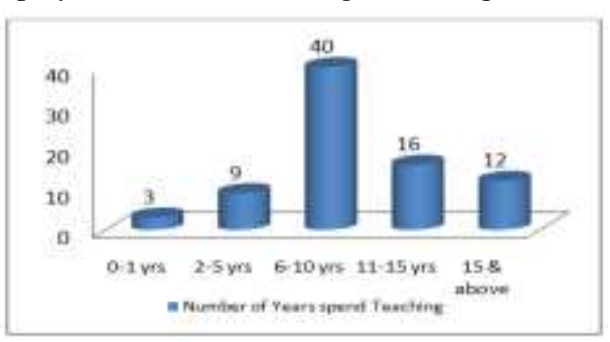

could therefore be put to bare or serve better in the polytechnic in terms of imparting

knowledge to learners.

Figure 2 Teaching Experience

7.2 What are the factors inhibiting polytechnic teachers' use of ICT in teaching and learning?

The main objective of this work was to find the general answer to this question. A multi-response analyses of the respondents answers is summarized in table 4

Table 4 Factors preventing teachers from using ICTs in their lessons in classrooms

\begin{tabular}{|l|l|l|l|}
\hline \multirow{2}{*}{ Cases } & Responses & \\
\cline { 2 - 4 } & Frequency & Percent & Rank \\
\hline $\begin{array}{l}\text { Inadequate LCD projectors in } \\
\text { classroom }\end{array}$ & 46 & $12.2 \%$ & 2 \\
\hline $\begin{array}{l}\text { Lack of knowledge about } \\
\text { computers }\end{array}$ & 59 & $15.7 \%$ & 1 \\
\hline Lack of confidence & 32 & $8.5 \%$ & 5 \\
\hline Fear for change & 24 & $6.4 \%$ & 8 \\
\hline Lack of training & 43 & $11.4 \%$ & 3 \\
\hline My age & 37 & $9.8 \%$ & 4 \\
\hline Little previous knowledge & 23 & $6.1 \%$ & 9 \\
\hline $\begin{array}{l}\text { Not sure how useful computer } \\
\text { are }\end{array}$ & 20 & $5.3 \%$ & 11 \\
\hline Computers are not accessible & 26 & $6.9 \%$ & 7 \\
\hline $\begin{array}{l}\text { Management doesn't care if I use } \\
\text { computer or not }\end{array}$ & 28 & $7.4 \%$ & 6 \\
\hline $\begin{array}{l}\text { Computer equipment is } \\
\text { unreliable }\end{array}$ & 17 & $4.5 \%$ & 12 \\
\hline $\begin{array}{l}\text { No support if something goes } \\
\text { wrong with computer }\end{array}$ & 21 & $5.6 \%$ & 10 \\
\hline Total & $\mathbf{3 7 6}$ & $\mathbf{1 0 0 . 0 \%}$ & \\
\hline
\end{tabular}

In a multi-response questioning, the cases are not mutually exclusive. In this regard, a total of 376 cases were obtained as seen in the above table. The three top responses came from Lack of knowledge about computers with 15.7\%; Inadequate LCD projectors in classrooms representing $12.2 \%$; and Lack of training being $11.4 \%$. A total of $37(9.8 \%)$ lecturers think they are too old to embrace the change in teaching methodology. The findings also point to a fact that the "old age" are the likely respondents who lack confidence $(8.5 \%)$ in using computers to teach. Further exploration of the responses shows that management is interested in the adoption of ICT in teaching and learning since only $7.4 \%$ think that Management does not care if they use computers. Another interesting finding is that the polytechnic has good technical support team. This is appreciated from the $5.6 \%$ who think they would not get technical support in case of computers malfunctions. Notions of fear for change in the teaching were appreciated though a minority $(6.4 \%)$. Interestingly, a few respondents consider the computers to be unreliable (4.5\%). Indeed, some inactive users of computers usually have this reservation.

In fact one can conclude as a deduction from the above expositions that the three (3) major barriers preventing the use of ICTs by teachers in Tamale Polytechnic are i) Lack of knowledge about computers ii) Inadequate LCD projectors in classrooms iii) Lack of training being

\subsection{Availability of ICT tools or equipment in the school.}

In trying to address this specific objective, respondents were asked whether they had sufficient computers, accessories and LCD projectors for use in their departments. As can be appreciated in table 5, only eight lecturers constituting $10 \%$ answered affirmatively. It was very possible that these responses might have come from the Computer Science department that has a number of computers for computer literacy lessons. The general opinion is that computers and accessories for lecturers' use are inadequate or do not exist.

Table 5: Existence of sufficient computers and accessories for lecturers' use.

\begin{tabular}{|l|l|l|}
\hline Response & Frequency & Percent \\
\hline Yes & 8 & 10.0 \\
\hline No & 72 & 90.0 \\
\hline Total & $\mathbf{8 0}$ & $\mathbf{1 0 0 . 0}$ \\
\hline
\end{tabular}

7.4 Adequate training in ICT to deliver lectures using computers

ICT capacity building exercises for lecturers in the polytechnic were found to be lagging behind. Only fifteen (15) out of the eighty (80) respondents believed they had received sufficient ICT training.

Even though the institution's management is interested in adopting ICT for teaching and learning, very little has been done to strategically achieve this objective (figure 3 ). 


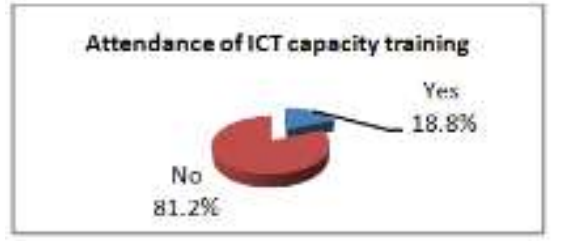

Figure 3 Attendance of ICT training

\subsection{The attitudes of teachers in the use of computers}

Attitude can be seen as a positive or negative sentiment according to Ajzen and Fishbein (1980). Smith et. al (2000) maintains that computer attitude evaluation usually encompasses statements that examine users' interaction with computer hardware, software, other persons relating to computers and activities that involve computer use. It was discovered that only eleven respondents (approximately $14 \%$ ) indicated that they use computers to prepare lecture notes and recording examination results. An interesting finding was that the remaining sixty nine (representing 86\%) who have never interacted with computers were willing to use them if they obtained the requisite skills.

\section{SUMMARY OF FINDINGS}

The study came up with the following findings:

The major factors that inhibit teachers from using ICTs in Tamale Polytechnic are ranked below:

i. Lack of knowledge about computers

ii. Inadequate LCD projectors in the classroom

iii. Lack of ICT capacity building to lecturers

iv. Age of lecturers

v. Lack of confidence

The least factors that were identified are:

vi. Lack of Management pressure on lecturers to use computers for teaching and learning

vii. Computers are not accessible

viii. Fear for change

ix. Lack of previous ICT knowledge

x. Insufficient technician support if something goes wrong with the computers

xi. Not sure how useful computers are

xii. The myth that computers are unreliable.

A number of by-findings were made:

i. Majority of the Tamale Polytechnic lecturers are closed to retirement.

ii. Majority of the lecturers are second degree holders whilst a few with terminal PhDs.

iii. Interviews with stakeholders indicated that the polytechnic has just established an ICT Services Directorate and has developed an ICT strategic plan for the period of $1^{\text {st }}$ January 2016 to $31^{\text {st }}$ December 2019 .

iv. The study revealed that even though government ICT policy on education provides a clear policy direction for what needs to be done, implementation has been very poor.

\section{RECOMMENDATIONS AND FUTURE} ENHANCEMENT
The research findings suggest the following recommendations: The management of the polytechnic should intensify ICT adoption campaign through sensitization and in-house capacity building workshops. This can be done easily using the lecturers from the Computer Science Department in collaboration with the ICT Directorate. Lack of the necessary competencies breeds lack of confidence and fear for change. In fact age affecting ICT competence is a wrong notion or a myth. Adequate trainings can resolve all these hindrances, making the lecturers abreast with the modern pedagogy of imparting knowledge and skills.

Committed funds from the polytechnic's IGF (Internally Generated Funds) and efforts should be exerted on acquiring laptops, LCD projectors and other equipment for audio visual teaching and learning. For example, acquisition of fifteen (15) laptops and fifteen (15) LCD projectors annually will allow the polytechnic to cover all its fifty eight (58) lecture halls with PowerPoint-enabled teaching aids.

Computer literacy should be made to score high marks in new lecturers' recruitment.

Polytechnic administrators should pay more attention to ICT investments in their business to derive the most. The way forward is IT and should be seen as such.

Governments of developing countries and for that matter Ghana, should now take a pragmatic approach towards realizing their ICT dreams. In most of these countries, public funds have been spent to develop very nice ICT policies and plans but implementations fail. A research to ascertain why the implementations of such plans in developing countries fail is highly recommended.

\section{REFERENCES}

[1] Balanskat, A., R. Blamire and S Kefala. "A review of studies of ICT impact on schools in Europe." European Schoolnet: European Communities (2006).

[2] Baylor, A. L. and D. Ritchie. "What factors facilitate teacher skill, teacher morale, and perceived student learning in technology-using classroom?" Computers \& Education (2002): 39(4), 395-414.

[3] Becker, Henry Jay. "How Are Teachers Using Computers in Instruction?" 2001 Meetings of the American Educational Research Association. Seattle: American Educational Research Association, 2001.

[4] BECTA. "A Review of the Research Literature on Barriers to the Uptake of ICT by Teachers." 2004. 19 Dec 2009

$<$ http://partners.becta.org.uk/page_documents/research/ barriers.pdf>.

[5] Beggs, T.,A. "Influences and barriers to the adoption of instructional technology." 2009. 19 Dec 2009 <http://www.mtsu.edu/ itconf/proceed00/beggs/beggs.h tm>.

[6] Bigum, Chris. "Teachers and computers: in control or being controlled?" Australian Journal of Education (1997): 41 (3): 247-261.

[7] Bingimlas, K. "Barriers to the Successful Integration of ICT in Teaching and Learning Environments: A Review of the Literature'." Eurasia Journal of Mathematics, Science and Technology Education (2009): 5(3), 235245. 
[8] Busha, Charles H. and Stephen P. Harter. Research Methods in Librarianship: Techniques and Interpretation. Michigan: Academic Press, 1980.

[9] Cavas, B., et al. "“A Study on Science Teachers' Attitudes Toward Information and Communication Technologies in Education'." The Turkish Online Journal of Educational Technology (2009): 8(2), 20-32.

[10] CISSSE, Lamine. "ECOWAS and the Daily Events: The Present Realities of the Integration Process within the Sub-Region ." GJA and FES (2006): 47.

[11] Cox, M.J. "What factors support or prevent teachers from using ICT in their classrooms?" British Educational Research Association Annual Conference. Brighton, 2000.

[12] DFES. The big pICTure: the impact of ICT on Attainment, Motivation and Learning. Nottingham: DfES, 2003.

[13] Drent, Marjolein and Martina Meelissen. "WWhich Factors Obstruct or Stimulate Teacher Educators to Use ICT Innovately?'." Computers and Education (2008): 51(1), 187-199.

[14] Dzidonu, Clement K. and et.al. The Ghana ICT for Accelerated Development Policy. Accra: Ministry of Communication, 2003.

[15] Ertmer, P. "“Addressing first-and second-order barriers to change Strategies for technology integration'." Educational Technology Research and Development (1999): 47(4), 47-61.

[16] Gomes, C. "Integration of ICT in science teaching. A study performed in Azores, Portugal." Recent Research Developments in Learning Technologies (2005).

[17] Gregoire, R., R. Bracewell and T. Laferriere. "The Contribution of New Technologies to learning and Technology in Elementary and Secondary School." (1996).

[18] Gressard, C., P. and B., H. Loyd. "“Age and staff development experience with computers as factors affecting teacher attitudes towards computers'." School Science and Mathematics (1985): 85(3), 203-209.

[19] Hawkridge, D. "(1990). Computers in Third World Schools. The example of China." British journal of educational technology (1990): 21 (I): 4-20.

[20] Hepp, P., et al. Technology in schools: Education, ICT and the knowledge society. : World. Washington, DC: The World Bank, 2004.

[21] Iddrisu, S.,A. Predictive validity of Senior High School (SHS) aggregate of students' grade-point average (gpa). Cape Coast, Ghana: Unpublished doctoral dissertation submitted to the Department of Educational Foundations, Faculty of Education, University of Cape Coast, 2009.

[22] Jegede, P., O. Dibu-Ojerinde and M. Llori. " "Relationships Between ICT Competence and Attitude Among Nigerian Tertiary Institution Lecturers'." Educational Research and Review (2007): 2(7), 172-175.

[23] Jenson, J., B. Lewis and R. Smith. "No one way: Working models for teachers' professional development'." Journal of Technology and Teacher Education (2002): 10(4), 481-496.

[24] Korte, W., B. and T. Husing. "“Benchmarking Access and Use of ICT in European Schools 2006:Results from Head Teacher and A Classroom Teacher Surveys in 27
European Countries'.” eLearning Papers (2007): 2(1), 16.

[25] Kozma, Robert B. "Will Media influence learning? Reframing the debate." Educational TechnologyRresearch and Development (1994): 42 (2): 7-19.

[26] Kozma, Robert, B. "Comparative Analysis of Policies for ICT in Education." Internatonal Handbook on Information Technology in Education (2008).

[27] Kumar, N., R.,C. Rose and J.,L. D'Sliva. "Teachers' Readiness to Use Technology in the Classroom: An Empirical Study." European Journal of Scientific Research (2008): 21(4), pp. 603-616. .

[28] Lee, D. "“Factors influencing the success of computer skills learning among in-service teachers'." British Journal of Educational Technology (1997): 28(2), 139141.

[29] Lowther, D. L., et al. "Does technology integration work when key barriers are removed?" Educational Media International (2008): 195-213.

[30] Matthew, K. "A Comparison of the Influence of Interactive CD-ROM Storybooks and Traditional Print Storybooks on Reading Comprehension." Journal of Research on Computing in Education (1997): 263-275.

[31] McGrail, E. "Teachers, Technology, and Change: English Teachers' Perspectives." Journal of Technology and Teacher Education, Norfolk, VA 13.1 (2005): 13 (1), pp. 5-24.

[32] MIE. Participatory teaching and learning, a guide to methods and techniques. Domasi, Malawi: Malawi Institute of Education, 2004.

[33] Muriithi, P. A framework for integrating ICT in the teaching and learning process in secondary schools in Kenya. Nairobi: Unpublished MSc. Thesis submitted at the University of Nairobi, School of computing andInformatics, 2005.

[34] OECD. "Education At a Glance: 2009 OECD Indicators." Organization for Economic Cooperation Development Publishing (2009).

[35] Omwenga, Elijah, T. Waema and P. Wagacha. "A model for introducing and implementing e-learning for delivery of educational content within the African context." African Journal of Sciences and Technology (2004): 5 (1), 35-48.

[36] Osborne, Jonathon and Sara Hennessy. "Literature Review in Science Education and the Role of ICT: Promise, Problems and Future Directions.” 2003.

[37] Pelgrum, W. and N. Law. ICT in Education around the World: Trends, Problems and Prospects. Paris: UNESCO, 2003.

[38] Pelgrum, W., J. “'Obstacles to the Integration ICT in Education: Results from a Worldwide Educational Assessment'." Computers and Education (2001): 37(2), 163-178.

[39] Rodden, N. An investigation into the barriers associated with ICT use in the Youthreach classroom: A case study of a centre for education in the North West. Limerick: Unpublished Master"s thesis,University of Limerick, 2010.

[40] Schoepp, K. "'Barriers to Technology Integration in a Technology-Rich Environment Learning and Teaching 


\section{International Journal of Computer Applications Technology and Research}

Volume 5-Issue 9, 595-602, 2016, ISSN:-2319-8656

in Higher Education: Gulf Perspectives." Learning and Teaching in Higher Education: Gulf Perspectives (2005): 2(1), 1-24.

[41] Sproull, Natalie, L. Handbook of research methods: A Guide for Practitioners and Students in the Social Sciences. Second Edition. Metuchen, N.J., \& London: The Scarecrow Press, Inc., 1995.

[42] Tezci, E. "“Teachers' effect on ICT use in education: the Turkey sample', ." Procedia Social and Behavioral Sciences (2009): (1)1, 1285-1294.
[43] Trotter, A. "Preparing teachers for the digital age." 2009. 5 Sept

2009 $<$ http://oak.cats.ohiou.edu/ waltje/classes/media2008/pr eparing.pdf $>$.

[44] Weert, T. V. and A. Tatnall. "Information and Communication Technologies and Real-Life Learning: New Education for the New Knowledge Society." Springer (2005).

[45] Yamane, Taro. "Statistics: an introductory analysis.". New York: Harper \& Row, 1973. 